DOI: $10.17951 / \operatorname{lrp} .2020 .39 .2 .9-21$

\title{
MAREK JEZIORAŃSKI
}

Catholic University of Lublin

ORCID - 0000-0002-9770-835X

\section{“THE CONTEMPORARY” AS A TELEOLOGICAL CATEGORY IN THE CONTEXT OF EDUCATIONAL RELATION}

\begin{abstract}
The aim of the article is to solve a problem expressed in the question: how "the contemporary" can be a teleological category in the context of the educational process. In response to this issue, an initial attempt was made to outline a map of pedagogical activity in the context of basic temporal references which include: retrospective orientation, contemporary orientation and prospective orientation. Then, on the basis of separately adopted temporal perspectives, an attempt was made to show them to formulate the basic objectives of upbringing. It has been concluded that the disconnection of these perspectives is not beneficial for the upbringing process, but rather their integration is an appropriate approach. This was called the postulate of the temporal integrity of pedagogy and two models of realization of this postulate were proposed: chronoagogic and kairoagogic.
\end{abstract}

Keywords: The Contemporary, temporal orientation, education, objectives of upbringing

The word "contemporary" nowadays appears very often in the scientific space of pedagogy and in general social sciences. It is expressed, for example, in the use of this term when formulating the titles of scientific conferences. For instance: "Education in the face of contemporary culture challenges: Opportunities and threats", "Education for the challenges of contemporary culture", or: "Teleological postulates of contemporary reflection and pedagogical activity".

In the title I have proposed, I tackle the topic o how "contemporaneity" can constitute a teleological category in the context of the educational process. One may also ask, why should contemporary times in general formulate challenges to education? If so, on the basis of what mandate is this approach justified? And if contemporaneity would already have the right to do so, shouldn't the same right be given to other temporal perspectives? 
In this article I will attempt to highlight a specific problem scenery, which is connected with the category "contemporaneity". Therefore, I will use the polemic method in order to open up particular areas of this issue by asking questions and then point to emerging possible solutions.

The article consists of four main parts. The first one, which is of an introductory nature, will show the context of the issue undertaken in the article. Next, a semantic analysis of 'contemporaneity' will be undertaken. The third part will show the teleological effects of a priori adoption of individual, of three main temporal orientations treated separately. At the last stage of the research, in conclusion, a solution to the problem will be proposed.

\section{INTRODUCTORY NOTE}

At the outset, it should be explained why the issues raised have been limited to the teleological aspect. It is also possible to ask whether it is appropriate to introduce any additional aspect to the previously assumed research. The reality of upbringing - as a social phenomenon - is very complex and multidimensional, hence it was necessary to adopt a certain point of reference that would in a sense simplify and order it so as to show the problem under consideration more clearly. The teleological approach was chosen because in some situations the term 'contemporary' and its derivatives appear as if in passing and are quite easily, even intuitively (or intentionally), combined with a specific, expected state of affairs, i.e. the purpose of upbringing. In other words, contemporaneity appears here as a kind of criterion in relation to which the upbringing process is to be programmed. It is in this sense that I have placed this question in the area of issues related to the aims of upbringing.

This is obviously not the only possible aspect of addressing this issue. Karol Kotłowski pointed out that pedagogical activity covers three planes in total: the sphere of facts, duties and praxeology (Kotłowski 1976, p. 21; Śliwerski 2012, p. 23). Therefore, the present day and other temporal perspectives can equally well be considered in relation to the sphere of facts and the sphere of educational praxeology. Below we will present a proposal for a comprehensive approach to the problem in the form of a scheme. It can be called: a map of pedagogical activity in the perspective of temporal references. The basis for these activities is the K. Kotłowski's distinction, with the addition that the sphere of praxeology will be treated in a wider sense and generally called: the way. The point is to take into account not only the principles, forms, methods and means of education in this element of the process of education, but - as Bogusław Śliwerski writes - this 
element is "a kind of a bridge leading from what is, to what should be" (Śliwerski 2010, p. 55).

Generally speaking, this bridge will manifest as both the intentional pedagogical activities and the broadly understood socio-cultural context. Marian Nowak presents "a sketch of 'the way' in which educational goals, types of values and norms are created" (Nowak 2008, p. 271). An important addition at this point is that the 'Way' is understood as an intersection of intentional and unintentional influences. This explains why the current educational situation (No. 4 in the table) is not a transformation of the previous situation based on assumed educational goals, but is a resultant of previously set intentions and additionally unintentional and unpredictable environmental influences. This is why situation no. 3, i.e. the state of the current educational situation postulated from the perspective of the past, cannot be identified with situation no. 4 , i.e. the actual current state of the educational reality. Similarly, situation no. 7 (the predicted shape of the future educational situation) will not be a full reflection of situation no. 6 (the postulated shape of the future educational situation), but will be similar to it, because situation no. 7 will also contain the unpredictable variables occurring in the socio-cultural context that - were excluded from no. 6. Of course, in the face of the prepared postulates directed to a specific educational situation, it is expected that they will be formulated in such a way that their degree of compatibility with the future real situation is as high as possible.

Table 1. The map of pedagogical activity in relation to the temporal perspective

\begin{tabular}{|c|c|c|c|c|c|c|}
\hline & & \multicolumn{2}{|l|}{ Facts } & \multicolumn{2}{|l|}{ Way } & Goals \\
\hline Past & 1 & $\begin{array}{l}\text { How it was? } \\
\text { Description of the causes } \\
\text { (sources) of the current } \\
\text { educational situation }\end{array}$ & 2 & $\begin{array}{l}\text { Recognizing and naming } \\
\text { the processes that led } \\
\text { from the state that was } \\
\text { to the state that is }\end{array}$ & 3 & $\begin{array}{c}\text { Normative projection } \\
\text { of reality in relation to } \\
\text { state } 1\end{array}$ \\
\hline Present & 4 & $\begin{array}{c}\text { How it is? } \\
\text { Description of the } \\
\text { current educational } \\
\text { situation taking into } \\
\text { account the socio-cultu- } \\
\text { ral context }\end{array}$ & 5 & $\begin{array}{l}\text { Recognizing and naming } \\
\text { the processes that } \\
\text { transform the current } \\
\text { educational situation } \\
\text { into what it will be. }\end{array}$ & 6 & $\begin{array}{l}\text { normative projection } \\
\text { of reality in relation to } \\
\text { condition } \mathrm{nr} 4\end{array}$ \\
\hline Future & 7 & $\begin{array}{c}\text { How it will be? } \\
\text { Opis przewidywanego } \\
\text { kształtu przyszłej sytua- } \\
\text { cji wychowawczej }\end{array}$ & 8 & $\begin{array}{l}\text { Anticipating and naming } \\
\text { the processes that will } \\
\text { continue to change the } \\
\text { educational situation. }\end{array}$ & 9 & $\begin{array}{c}\text { Normative projection } \\
\text { of reality in relation to } \\
\text { condition } \mathrm{nr} 7\end{array}$ \\
\hline
\end{tabular}

Source: own work. 


\section{UNDERSTANDING OF THE CONTEMPORARY}

In accordance with the assumptions, this article will undertake research related to the presentation of the educational responsibility (educational goals) depending on the adopted time perspective. In the first stage, however, it is necessary to start with the presentation of the definition of the contemporaneity. The following sources were analyzed: Encyclopedia of pedagogy of the 21st century, Universal Encyclopedia of Philosophy, Encyclopedia of Sociology, Encyclopedia of Pedagogical Axiology, Catholic Encyclopedia, Beltz Lexikon Pädagogik, Klinkhardt Lexikon Erziehungswissenschaft, Internet Encyclopedia of Philosophy. None of them provide an explanation for the term sought. This means that the term cannot currently be used as a category, i.e. - according to I. Kant and later M. Heidegger - a certain way of thinking through which the reality being learned is put in order (Maryniarczyk 2004, p. 545). It can also be concluded that its popularity is connected with common understanding, which in turn may give rise to many misunderstandings and contradictions. It is all the more justified to subject this issue to scientific reflection.

The Polish PWN dictionary defines "contemporaneity" as: "(1) what is or was contemporary to someone; (2) things, events contemporary to someone, especially: present times; (3) the occurrence of some facts, events at the same time".

The last (3) proposal deserves special attention. The previous two commit an ignotum per ignotum fallacy. The last proposal, on the other hand, is about the co-occurrence of facts at the same time. The dictionary of the Polish language edited by Witold Doroszewski adds the term "simultaneity" as synonymous . It is not explained further what the statement "same time" means, is it one moment or 10 years? In other words, can contemporaneity (simultaneity) be identified with the present and if so, to what extent.

The above review of sources shows that the term "contemporaneity" is very rarely defined, and even then, only in the area of the language science. It is understood as the co-occurrence of various facts and phenomena.

This explanation is of course important, however, there remains the problem of defining the limits of co-occurrence, can we speak about it only in the area of few seconds (minutes, hours) or years? This is the first important difficulty in using this term. Certainly, it is impossible to set unambiguous time limits defining the present day and for various types of pedagogical research they can be defined in a different way, however, there is no doubt that through this term the temporal perspective is clearly included.

Barbara Fatyga's proposal is an important addition to the definition of the limits of meaning of the analyzed term. She has been reflecting on the previously 
proposed periodization of time in the study of social reality according to Elżbieta Tarkowska, who has distinguished herself:

1. The distant past - beyond the borders of one's own biographical horizon.

2. The close past - within its own biographical horizon.

3. The present - a monolith.

4. The near future - within its own biographical horizon.

5. The distant future - beyond the boundaries of one's own biographical horizon.

B. Fatyga presented her supplements concerning the present in her lecture "Lifestyle from the perspective of living culture. How Young People Reproduce Society", which was delivered during the XXXII Summer School of Young Educators (Łagów Lubuski, 19.09.2018). For this researcher, the present can be understood as:

1. The near present - here and now: it is a situation of the connection between time and space.

2. The distant present is the separation of time and space from one side, and from the other it is a combination of (very) distant places at one time. Such a possibility is created by the Internet, for example, today.

It is an important complement, because it allows for a more precise understanding of the present day by the dimension of space. It is therefore assumed that it will be a co-occurrence of various facts and phenomena in a given geographical space. Such a 'limitation' of contemporaneity is not intended to contravene theories and analyses of social phenomena based on a different understanding, such as the paradigm of a 'global teenager' (Melosik 2007), and is only an attempt to facilitate further research in the development of specific theoretical models showing the dependence of the goals set in upbringing on the adopted temporal perspective.

\section{THE PRESENT DAY IN THE CONTEXT OF OTHER TEMPORAL REFERENCES AND THEIR TELEOLOGICAL SIGNIFICANCE}

In the next step, it is worth posing a question about the importance of contemporaneity and other temporal references for upbringing. This then raises the question about the choice of proper temporal orientations, which in turn relates to axiological issues. Thus, another perspective (apart from the teleological one) of the consideration of 'contemporaneity' is signalled. It can be assumed many times that the acceptance of the criterion of contemporaneity positively evaluates the problem. 
In the field of social sciences, Elżbieta Tarkowska was the one who dealt with the issue of time. She distinguished eight types of temporal orientation (Tarkowska 1987, pp. 148-149):

\begin{tabular}{|c|c|c|}
\hline $\begin{array}{c}\text { Type of temporal } \\
\text { orientation }\end{array}$ & $\begin{array}{c}\text { Favoured time zone } \\
\text { (i.e. valid and positively evaluated) }\end{array}$ & $\begin{array}{c}\text { Depreciated area of time } \\
\text { (this one is important and rated negative) }\end{array}$ \\
\hline A & Past, Present, Future & None \\
\hline B & Past, Present & Future \\
\hline C & Past, Future & Present \\
\hline D & Present, Future & Past \\
\hline E & Past & Present, Future \\
\hline F & Present & Past, Future \\
\hline G & Future & Past, Present \\
\hline H & None & Past, Present, Future \\
\hline
\end{tabular}

From the above list, only those temporal orientations will be selected which positively value only one area of time, i.e. either the past (orientation E), or the present (orientation F), or the future (orientation G). On their basis an attempt will be made to assess the significance of these temporal references for upbringing. This issue will be addressed in two ways. In the first stage, the chosen temporal perspective will be synthetically presented, and then it will be then related to the telelological context of the upbringing process. In other words: I will try to look at the chosen time perspective as accepted criteria in defining the objectives of education.

\section{TELEOLOGY OF UPBRINGING \\ IN THE CONTEXT OF RETROSPECTIVE ORIENTATION}

E. Tarkowska explains that the E-type orientation "is a positive retrospective orientation or, from another point of view, a negative presentational-prospective orientation. Only the past is important, other areas of time are rejected. This is expressed in idealizations of the past, in various forms of escape from the present and the future. This type of orientation is characteristic of extreme conservatism in terms of social movements and ideology" (Tarkowska 1987, p. 150).

In this perspective, the past is a constant point of reference for the formulation of upbringing goals. Everything is valued in the context of a 'proven past'. This approach corresponds to the perennialistic position in pedagogy, which expresses the conviction that "the most important principles of upbringing are unchangeable and never lose their validity" (Gutek 2007, p. 281), but their source 
is a study of the past. In this perspective, pedagogy is primarily concerned with developing upbringing programmes that take into account the most universal human characteristics. It is connected with a greater interest in human nature as a determinant of upbringing. At this point it is possible to point out such features of upbringing resulting from adopting a retrospective perspective as, for example: greater openness to ideas, values, general, humanistic thinking in the context of human development and not only focusing on current problems and situations. This is due to the adoption of a long temporal perspective. The perspective of the past also gives the possibility of axiological confrontation.

On the other hand, however, what does not fit the cliché of past patterns is rejected (or at least negatively valued). In this perspective it is also possible to subordinate the current reality to perennialistic educational models. This, in turn, results in a lack of openness to new solutions, a lack of presence in the present. At best, the present is always some kind of "emanation of the past", so one should always look to past times for ways to solve current problems.

M. Nowak points to the danger of "escaping into the past", i.e. referring to tradition, idealizing the past and nostalgia for it. In educational practice, such an attitude may manifest itself in using an authoritarian style of upbringing or forcing obedience (Nowak 2008, p. 338).

\section{TELEOLOGY OF UPBRINGING IN THE CONTEXT OF GIFT ORIENTATION}

In E. Tarkowska's description type F Orientation (i.e. Presentist-positive orientation) "consists in absoluting the present while negating other areas of time. This orientation has been repeatedly described for various purposes as 'orientation for the present moment', 'living the moment' etc.” (Tarkowska 1987, p. 150) The most characteristic elements of this orientation are the importance of immediacy, concreteness and action. In a further description, the researcher explains that "it is often accompanied by hedonism or opportunism - maximisation of pleasure or immediate benefits, and at the same time freedom and spontaneity of action" (Tarkowska 1987, p. 150). One of the negative components of this orientation is the attitude related to the escape from spiritual values as rooted in the past, which can lead to such phenomena as vandalism, drug addiction, irresponsible procreation (Tarkowska 1987, p. 150). It is also worth noting that in comparison with the other two temporal orientations, the presentational approach is very short in time.

When taking a Presentist temporal orientation as a starting point for constructing upbringing goals, the following consequences can be pointed out: focusing 
on what is current, immediate and also: tactile, concrete, visible, perceptible. With regard to the division of objectives by Bogdan Suchodolski, one should recall the importance of close goals (Nowak 2008, p. 347), which are characterized by quick and concrete realization and the possibility of clear verification of their achievement.

In this perspective, the following shortcomings can be distinguished: lack of interest in the genesis and development of phenomena and lack of openness to procedural or ideological thinking. M. Nowak notes that this may lead to what he calls "indifference and resignation from thinking" - uncritical acceptance of the current reality. Mixing and confusion between apparent and real values may result from this approach (Nowak 2008, p. 338). The short duration of this temporal perspective also induces those who rely on it to verify their educational goals frequently and continuously.

An unquestionable advantage of this temporal perspective is that it takes into account current social and cultural situations in education. Moreover, adopting this temporal perspective helps to design a more appropriate upbringing, especially with regard to its pragmatic dimension.

\section{TELEOLOGY OF EDUCATION IN THE CONTEXT OF PROSPECTIVE ORIENTATION}

This type of temporal orientation (type G) is presented by E. Tarkowska in the following way: "Positive prospective orientation, related to negating the meaning of the present and the past" (Tarkowska 1987, p. 151). This orientation is characterized by an approach focused on innovative activities and is related to dreamer individuals. Within its framework, an attitude of passive waiting for the desired shape of the future may arise - this happens when the relationship between the future and the present is denied, which is found in this type of temporal orientation (Tarkowska 1987, p. 151).

In this approach, upbringing goals are built on the predicted shape of the future social situation. The first pedagogical problem which emerges on the basis of future-oriented upbringing is the question whether this temporal perspective is not the "home" of pedagogy, since - as Stefan Kunowski writes - its subject is "the developmental good of man not currently understood, but realized in the future, oriented towards the future" (Kunowski 2004, p. 39). Another example justifying this position is the statement of Mufti Dr. Nedal Abu Tabaq, director of the Islamic Cultural Centre in Lublin, who, as part of his speech at the conference entitled "Education to interreligious dialogue - Catholics and Muslims in Poland” (23.03.2011, KUL) quoting Ali Ibn Talib, said: “Do not talk to children by 
the measure of your wits, for they were created for a different time than yours". These exemplary statements see the future as the source of the goals of education.

It should be stated that constructing educational goals on the basis of a prospective perspective leads first of all to perceiving possibilities, setting directions and plans, and less to their realization. In this context it can be stated in general terms that what is possible is real.

Recalling the classification of goals by B. Suchodolski, the main focus is put on distant goals (Nowak 2008, p. 347), i.e., those characterised by a long process of implementation, without the possibility of unequivocally stating whether the assumed goals were achieved. However, they constitute something that can be called "life's driving force" because, as they are never fulfilled and closed, they are always a challenge to undertake the (next) task.

The danger of a prospective education is "a life that does not and may never be". In this perspective, the least valued area of upbringing is pragmatic upbring and the strongest is general upbringing, understood in the sense of a certain independence of the upbringing from the social context, as Rousseau preached already in the 18th century: "to live is the profession that I want to teach them. Coming out of my hands, he (Emil) will not be, I admit, either a clerk, or a soldier, or a priest, he will first be a man, whatever he may be, he will know how to be in need; fate may move him from one position, he will always find himself in the right place. Looking at the changeability of human things, at the restless and lively spirit of this age, which is turning everything over in every generation, is it possible to grasp a more thoughtless method like bringing up a child as if it were never to leave its room..." (Cat 1996, p. 21). It is therefore a matter of focusing on general, philosophical education, detached from social contexts, because only such education can properly prepare a pupil to enter the future, unknown world.

\section{CONCLUSION}

From the above, it can be concluded that there are no grounds for being overly attached to any temporal perspective making it the sole determinant of teleological decisions. Each of the positions shown above has elements that could be called positive or negative. Of course, their assessment will depend on the ontological, anthropological and axiological assumptions made earlier, but nevertheless, opting for one of the chosen temporal perspectives with the unequivocal exclusion of the others always results in the exclusion of some important areas of education.

The solution to the problem posed at the beginning may be the introduction of a fourth type of temporal orientation, an orientation covering the entire time 
continuum. For this orientation it is important to "experience time as a continuum", sensitivity to the constant flow of time, sense of continuity and continuation. There is no room for violent breakthroughs and changes in this optics. However, the faith in human development possibilities present here does not allow for radical changes. This orientation is often described as the most valuable because it maintains a balance between adaptation, status quo and innovation (Tarkowska 1987, p. 148).

It seems, therefore, that the most appropriate approach for pedagogy is to adopt the last model of temporal orientation: the temporal continuum. Even if, in certain research or educational circumstances, the focus is more intense on one perspective: retrospective, presentational or prospective, one should not be completely deprived of reference to the other two. This can be called the postulate of the temporal integrity of pedagogy.

At this point I would like to propose two models of realizing this postulate in the educational process. They are based on an ancient Greek understanding of time, which was defined by two terms: Xpóvo - Chronos - and Kaıpó - Kairos (Popowski 2006, p. 694). Time, in the sense of Chronos, indicates the location of the course of successive events. Time as understood in this way is an ordering matrix, which makes it possible to order individual events while determining their temporal distance from each other. In this situation time units such as year, month, week, day, hour etc. are indicated. Its passage is constant and is not conditioned by human activity. Time in the sense of Kairos is explained as: the right moment, the right time, the correct instant, the appropriate period, the right opportunity (Popowski 2006, p. 311). In this sense it is the right time for something. Thus, it constitutes the occurrence of a happy moment, which may or may not be used (Kogler 2011, p. 332). Thus, it is individualized and its appearance is conditioned not only by a specific set of phenomena, but also by the proper human reaction to these phenomena. At this time, the value of human activity, which is in a way a skilful response to the situation, is emphasised.

In relation to the above, there are two models of implementing the postulate of temporal integrity of pedagogy. The first will be based on the understanding of time as Chronos and can be called chronoagogic, while the second will be based on the understanding of time as Kairos and can be called kairoagogic. The proposed names are the result of a combination of two components: the specificity of the understanding of the tense and the educational dimension, which is expressed by the inclusion of the Greek verb $a \gamma \omega$ (I lead). The point is to indicate, already in the name itself, the educational potential of the tense, and not just a reflection on it (chronological, kairological) or its description (chronographical, kairographic) in the context of education. 
The first model encourages researchers to take into account the time context of the phenomenon under investigation. It respects the processional understanding of social phenomena, taking into account their sources and consequences. Time is an objective and absolute reality in this model. In this arrangement, the educational work will consist in taking into account, as far as possible, all events related to the pupil, analysed in the context of what led to them, how they were experienced or worked out by the pupil and what they may lead to in the future. The process of education is understood as a continuum.

The second model encourages researchers to identify special events in the life of the pupil. Their particularity lies not only in the fact that they had, have or may have a great significance in the personal development process of the pupil. The uniqueness of these phenomena lies primarily in that: 1) not only their content, but also their course are a result of the social context and the activity of the pupil himself/herself used in response to the identified circumstances; 2) the linear temporal perspective breaks down. These are events which, regardless of whether they took place in the past, take place in the present or are planned in the future, are constantly present in the pupil. In other words, exceptional events 'happen' all the time in the childhood and thus contain educational potential.

\section{SUMMARY}

The aim of the presented article is to solve the problem expressed in the question: how "the contemporary" can be a teleological category in the context of the educational process. In response to this question, an initial attempt was made to outline a map of pedagogical activity in the context of basic temporal references, which include the following orientations: retrospective, presentational and prospective. Then, on the basis of the separately adopted temporal perspectives, an attempt was made to show their significance for the formulation of basic educational goals.

It was concluded that the separate presentation of the above perspectives is not beneficial for the process of upbringing, but the proper approach is to integrate them. This was called the postulate of temporal integrity of pedagogy and two models of realization of this postulate were proposed: chronoagogic and kairoagogic.

\section{REFERENCES}

Beltz Lexikon Pädagogik, 2012, H.-E. Tenorth, R. Tippel R. (eds.), Weinheim, Basel, Beltz Verlag. 
Encyklopedia aksjologii pedagogicznej, 2016, K. Chałas, A. Maj (eds.), Radom, Polskie Wydawnictwo Encyklopedyczne.

Encyklopedia katolicka, T. 1-20, 1995-2014, F. Gryglewicz et al. (eds.), Lublin, Towarzystwo Naukowe KUL.

Encyklopedia pedagogiczna XXI. T. I - Suplement, 2003-2010, T. Pilch (ed.), Warszawa, Wydawnictwo Akademickie Żak.

Encyklopedia socjologii, T. I - Suplement, 1998-2005, Z. Bokszański (ed.), Warszawa, Oficyna Naukowa.

Gutek G.L., 2007, Filozofia dla pedagogów. Gdańsk, GWP.

Horn K.-P., Kemnitz H., Marotzki W., Sandfuchs U. (eds.), 2012, Klinkhardt Lexikon Erziehungswissenschaft. Bad Heilbrunn, Verlag Julius Klinkhardt.

Internet Encyclopedia of Philosophy, https://www.iep.utm.edu/ [access from: 20.10.2018]. Kot S., 1996, Historia wychowania. T. II, Warszawa, Wydawnictwo Akademickie Żak. Kotłowski K., 1976, Aksjologiczne podstawy teorii wychowania moralnego. Wrocław, Warszawa, Kraków, Gdańsk, Ossolineum.

Kunowski S., 2004, Podstawy współczesnej pedagogiki. Warszawa, Wydawnictwo Salezjańskie.

Maryniarczyk A., 2004, Kategorie. In: A. Maryniarczyk (ed.), Powszechna encyklopedia filozofii. T. V, Lublin, Polskie Towarzystwo Tomasza z Akwinu, 539-545.

Melosik Z., 2007, Teoria i praktyka edukacji wielokulturowej. Kraków, Oficyna Wydawnicza Impuls.

Nowak M., 2008, Teorie i koncepcje wychowania. Warszawa, Wydawnictwo Akademickie i Profesjonalne.

Nowy leksykon biblijny, 2011, F. Kogler (ed.), Kielce, Wydawnictwo Jedność.

Popowski R., 2006, Wielki słownik grecko-polski Nowego Testamentu. Warszawa, Oficyna Wydawnicza „Vocatio”.

Powszechna encyklopedia filozofii. T. I-X, 2000-2009, A. Maryniarczyk (ed.), Lublin, Polskie Towarzystwo Tomasza z Akwinu.

Śliwerski B., 2010, Współczesne teorie i nurty wychowania. Kraków, Oficyna Wydawnicza Impuls.

Śliwerski B., 2012, Pedagogika ogólna. Podstawowe prawidłowości. Kraków, Oficyna Wydawnicza Impuls.

Tarkowska E., 1987, Czas w społeczeństwie. Problemy, tradycje, kierunki badań. Wrocław, Wydawnictwo Polskiej Akademii Nauk.

Współczesność, In: Słownik języka polskiego PWN, W. Doroszewski (ed.), https://sjp. pwn.pl/doroszewski/wspolczesnosc;5518219.html [access from: 21.12.2018]; https:// sjp.pwn.pl/szukaj/wsp\%C3\%B3\%C5\%82czesno\%C5\%9B\%C4\%87.html [access from: 21.12.2018]. 


\section{„WSPÓŁCZESNOŚĆ” JAKO KATEGORIA TELEOLOGICZNA W KONTEKŚCIE RELACJI WYCHOWAWCZEJ}

Streszczenie: Celem artykułu jest rozstrzygnięcie problemu wyrażonego w pytaniu: w jaki sposób „współczesność” może być kategorią teleologiczną w kontekście procesu wychowawczego? W odpowiedzi na postawione zagadnienie podjęto na wstępnie próbę zarysowania mapy działalności pedagogicznej w kontekście podstawowych odniesień temporalnych, do których należą: orientacja retrospektywna, prezentystyczna i prospektywna. Następnie na podstawie przyjmowanych odrębnie perspektyw temporalnych starano się ukazać ich wpływ na formułowanie podstawowych celów wychowania. Stwierdzono, że rozłączne ujmowanie powyższych perspektyw nie jest korzystne dla procesu wychowania, a właściwym podejściem jest ich zintegrowanie. Nazwano to postulatem integralności temporalnej pedagogiki i zaproponowano dwa modele realizowania tego postulatu: chronoagogiczny i kairoagogiczny.

Słowa kluczowe: współczesność, orientacja temporalna, wychowanie, cele wychowawcze 